\title{
History of Education as a Changing Research Field
}

\author{
Iveta Kestere, Irena Stonkuviene and Veronika Varik
}

\begin{abstract}
This study focuses on the 1990s, when the well-organised community of Baltic educational historians faced the challenges of a changing political system. Researchers who had previously worked under strict authoritarian rule had to accomplish three tasks: 1) create a new narrative of the history of education of the Baltic states, emancipated from Soviet ideology, and explain sources available in the newly-opened archives; 2) learn to "sell" (at conferences and through publications) their stories to a foreign audience of historians; and 3) become involved in the global community of educational historians. Our sources are monographs on the history of education and 41 doctoral theses developed in the Baltic states. These sources were confronted by academic studies from internationally recognised scholars in various regions, characterizing global trends in the current history of education. We developed a model of requirements and analysed how the supply from the Baltic states complied with global trends in the history of education. We conclude that the national history of education was rewritten by getting rid of the simplified Soviet "class struggle" stories, and also fulfilled the demands of the local community, that is, confirming the importance of education for uplifting a nation and proving the long standing connection between the Baltics and Europe. The development of education in the Baltic countries was primarily explained in a frame of European political history and not the history of education. Communication with the global community of historians of education formed slowly: on the one hand, information about their activities was lacking and finances and foreign language knowledge was insufficient, but on the other hand, nationally-oriented stories about history filled with local facts were just politely regarded by an international audience. From the perspective of the global history of education, studies in the Baltic states about education of specific social groups (e.g., ethnicity and disability) were more up-to-date.
\end{abstract}

Keywords: history of education, national narratives, doctoral theses, Baltic states

\section{Introduction}

At the end of the 1980s with the advent of political freedom for the Baltic states, historians, including historians of education, become a popular community of busy scholars who were required to fulfil several tasks. Baltic historians met the public demand for creating a "new" history for the renewed nation-states, a history useful for restoration and uplifting of national self-confidence. Also, historians themselves were willing to restore their professional reputations that had suffered greatly during the Soviet era when history fulfilled political propaganda functions, most notably the legitimisation of incorporation of the Baltic nations into the Soviet Union and in defence of the advantages of Soviet life (as compared to the period of Baltic independence during the 1920s-1930s). In 
this context, the first contacts with Western colleagues, previously inaccessible behind the Iron Curtain, also began to develop.

The purpose of our article is to analyse the activities of educational historians in the Baltic States in three directions, namely, the creation a new narrative for national history, explanation of these narratives to the world, and integration into the global community of historians of education.

Our sources are monographs and collections of articles in the history of education, as well as doctoral thesis developed in the Baltic countries from 1990 to 2004 . There were 41 theses, 10 of them developed in Estonia, 8 in Latvia, and 23 in Lithuania (see Table 1).

\section{Creation of a "new" national history of education}

The popularity of national history during periods of social transformation has been apparent since the rise of national movements in mid-19 ${ }^{\text {th }}$ century. Writing national history accompanied the creation of the nation state: "Nation

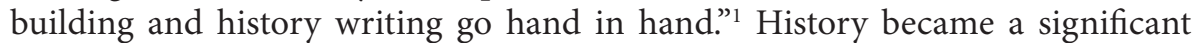
building block to construct (and re-construct) national identity in the former Soviet republics, ${ }^{2}$ which had suffered greatly under Russian domination. In the 1990s, a "new" history, both in terms of facts and public significance, emerged in the Baltic states. ${ }^{3}$

Ability to liberate from the dictatorship and restore independent states in the Baltic's was explained with preserving of national traditions, values and collective memories throughout the years of Soviet occupation. A significant and positive role was given to the national identity safeguarded through "unofficial education" (for example, in families). ${ }^{4}$ After regaining independence, a new history gave a clear message to the public: a sense of togetherness helped defeat dictatorship and regain freedom. Researching and learning national history gained popularity and became the answer to totalitarianism ${ }^{5}$ where "international" was synonymous with "socialistic camp", historians had limited access to sources, publications were censored, and the central narrative was about the history of education in Russia.

1 D. Tröhler, 'Tracking the Educationalization of the World: Prospects for an Emancipated History of Education', Pedagogika, vol. 67, no. 3, 2017, p. 213.

2 See M. Tamm, 'Writing Histories, Making Nations: A Review Essay', Storicamente, no. 12, 2016, p. 2.

3 See Estonian case in M. Carretero, Construction Patriotism. Teaching History and Memories in Global Worlds, Charlotte, North Carolina, IAP, 2011, pp. 38-47.

4 A. Abens, 'Effects of Authoritarianism on the Teaching of National History: the Case of Latvia, Paedagogica Historica, vol. 51, no. 1-2, 2015, pp. 166-180; G. Abols, Contribution of History to Latvian Identity, Riga, Nacionālais apgads, 2003; M. Carretero, Constructing Patriotism. Teaching History and Memories in Global Worlds, Charlotte/North Carolina, Information Age Publishing, Inc., 2011, p. 41.

5 See A. Nobik, I. Kestere, J. Gulzynska, 'History of Education Journals and the Development of Historical Research on Education in Eastern Europe (1990-2016), International Journal for the Historiography of Education, no. 2, 2019, pp. 141-155. 
By the end of the 1980s, historians eagerly went through archives that were previously secret but were now partially and/or completely open and available. First and foremost, historians of education focused on the study of education history during the period of Baltic independence from 1918 to 1940 . We can find several explanations why this period seemed so attractive.

First, the 20 years of Baltic independence were harshly attacked by Soviet ideology: the period was labelled as "bourgeois" and all events in education were reduced to explanations of how workers and peasants fought with capitalists to be allowed to pursue education. Every remark about Baltic independence was carefully censored and, inevitably for historians, this meant applying ideology and creating a fraudulent story. Yet, in public memory, independence remained the "Golden Age" when the Baltic states prospered and flourished both in terms of economy and also in culture and education. Myths about state independence were secretly passed down from one generation to the next. Therefore, it is logical that historians desired to clarify what really happened in Baltic education during the 1920s-1930s.

Second, very little research was done on sources from 1918-1940 (documents, books, and mass media) as permission for special access was required during the Soviet era. Although it wasn't difficult for professional historians to receive authorisation, it still meant uncomfortable contact with Soviet bureaucracy.

Third, 1918-1940 sources were usually available in the national languages; therefore, it was easier and faster to analyse them.

For these reasons, the interwar period became the first topic historians restored from oblivion and presented in the public space. Until 2004, several monographs of educational historians were published in Latvia, ${ }^{6}$ Estonia, ${ }^{7}$ and

6 L. Žukovs, A. Kopeloviča, Skolotāju izglītība un pedagoǵiskā doma Latvijā [Education of teachers and pedagogical thought in Latvia], Rīga, RaKa, 1997; A. Staris, V. Ūsinš̌, L. Žukovs, Skolas un izglìtība Latvijā. 1900-1920 [Schools and education in Latvia. 1900-1920], Rìga, RaKa, 2000; A. Stairs, V. Ūsiņš, Izglìtības un pedagoğijas zinātnes attīstība Latvijas pirmās brīvvalsts laikā [Development of education and pedagogy science during the first independence period of Latvia], Rīga, Zinātne, 2000; A. Staris, Skolas un izglìtība Rīgā no sendienām lìdz 1944 [Schools and education in Riga from olden days to 1944], Lielvārde, Lielvārds, 2000; J. Anspaks, Pedagogijas idejas Latvijā [Pedagogical ideas in Latvia], Rīga, RaKa, 2003.

7 L. Andresen, Eesti rahvakooli ja pedagoogika ajalugu, I: Eellugu ja algus kuni Põhjasõjani [History of Estonian folk school and pedagogy. Vol. 1: From prehistory to the Northern War], Tallinn, Avita, 1997; T. Karjahärm, V. Sirk, Eesti haritlaskonna kujunemine ja ideed 1850-1917 [Formation and ideas of Estonian intelligence 1850-1917], Tallinn, Eesti Entsüklopeediakirjastus, 1997; L. Andresen, Eesti rahvakooli ja pedagoogika ajalugu, II: Kaheksateistkümnes sajand [History of Estonian folk school and pedagogy. Vol. 2: 18 ${ }^{\text {th }}$ Century], Tallinn, Avita, 1999; A. Liim (ed.), Haridusinstitutsioonid Eestis keskajast kuni 1917. aastani [Educational institutions in Estonia from the middle ages until 1917], Tartu, Eesti Rahvusarhiiv, 1999; L. Andresen, Eesti rahvakooli ja pedagoogika ajalugu, III: Koolireformid ja venestamine (1803-1918) [History of Estonian folk school and pedagogy. Vol. 3: School reforms and russification (1803-1918)], Tallinn, Avita, 2002; V. Paatsi, Eesti talurahva loodusteadusliku maailmapildi kujunemine rahvakooli kaudu (1803-1918) [Formation of the natural science outlook of Estonian peasants through country schools (1803-1918)], Tallinn, Tallinna Pedagoogikaülikooli kirjastus, 2003. 
Lithuania, ${ }^{8}$ focusing on national education from its origins up to 1940. These are studies about education management; the history of various education establishments (mostly elementary and secondary education); curricula; descriptions of student bodies; teacher training, teaching staff and their social conditions; and the history of pedagogical ideas.

Yet another topic prohibited by the Soviets but now restored was the exile Baltic community in West. ${ }^{9}$ During World War II, millions of Europeans became exiles, ${ }^{10}$ and amongst them were hundreds of thousands of inhabitants of the Baltic states who feared the repressive measures of Stalin and did not want to live in the USSR. ${ }^{11}$ Baltic refugees created a wide network of education institutions from kindergartens to a university in their new homelands. But information about the Baltic community in exile was hidden by the Soviet Union or delivered in a very distorted and negative way. Hence, education in Western exile became a fresh area of study for "new" national histories.

We must also mention the first reflections about education during the Soviet occupation. ${ }^{12}$ The Soviet story can be added to studies of recent history that is inevitably tainted with subjectivity and politics. However, when writing about the Soviet history of education, people raised in the USSR had some advantages: they had knowledge or knew the decryption codes that helped

${ }^{8}$ R. Motuzas, Lietuvos vidurines mokyklos raidos $1918-1940$ metais pedagogines kryptys [The pedagogical trends in the development of Lithuanian secondary school in 1918-1940], Vilnius, Leidybos centras, 1995; O. Tijūnèlienè, Pedagoginiai santykiai Lietuvoje (1900-1940) [Pedagogical relations in Lithuania (1900-1940)], Klaipėda, Klaipėdos universiteto leidykla, 1996; S. Valatkiene, "Naujojo ugdymo" sajüdis Vakaruose, jo idëju atspindys Lietuvoje (1918-1940) [The movement of "New Education" in the West, reflection of its ideas in Lithuania (1918-1940)], Vilnius, VU leidykla, 1997; S. Kaubrys, Lietuvos mokykla 1918-1939 m.: galios gimtis [The Lithuania school in 1918-1939: birth of power],Vilnius, Vieš. įstaiga "Statistikos tyrimai," 2000; O. Tijūnèliene, Mokytojo autoriteto samprata Lietuvoje (1918-1940) [The concept of teacher's authority in Lithuania (1918-1940)], Klaipėda, Klaipèdos universiteto leidykla, 2000 .

9 S. Montvilaite, 'Lietuvių mokyklos perkeltujų asmenų stovyklose Vokietijoje 1945-1950 metais' [Lithuanian Schools in the Camps for "Displaced Persons" in Germany in 1945-1950], Acta Paedagogica Vilnensia, no. 4, 1997, pp. 44-51; K. Pečkus, JAV lituanistinio švietimo ir lietuviu egzodo pedagogikos istorijos bruožai [The features of history of Lithuanian education and Lithuanian exodus pedagogy in the USA], Vilnius, Lietuvos Respublikos švietimo ir mokslo m-jos Leidybos centras, 1997; A. Staris (red.), Rietumu trimdas latviešu pedagogiskā doma (1944-1990). Antologija [Latvian pedagogical thought in the Western exile (1944-1990). Anthology], Rīga, RaKa, 2004; V. Rajangu, M. Meriste, Eesti koolid ja eesti keele õpe välismaal [Estonian schools and the Estonian language tuition abroad], Tallinn, Tallinna Tehnikaülikool, 1995.

${ }^{10}$ I. Zake, Politics of a Refugee Community. American Latvians, New Brunswick (USA) and London (UK), Transaction Publishers, 2010, p. 29.

${ }^{11}$ L. Zalkans, Back to the Motherland. Repatriation and Latvian Émigrés 1955-1958, PhD diss., University of Stockholm, 2014, p. 50.

12 A. Staris (red.), Pedagoǵiskā doma Latvijā no 1940.gada lìdz mūsdienām [Pedagogic thought in Latvia from 1940 until today], Rīga, Puse, 1998; J. Ant, Eesti 1939-1941: rahvast, valitsemisest, saatusest [Estonia 1939-1941: People, governance, fate], Tallinn, 1999; A. Jürgenson, Siberi eestlaste territoriaalsus ja identiteet [The identity and territoriality of Siberian Estonians], Tallinn, Tallinna Pedagoogikaülikooli kirjastus, 2002. 
evaluate censorship in sources, propaganda and "rewritten" Soviet style history. Sometimes, the Soviet political and ideological context was so absurd that people (including historians) born and raised in democratic countries simply could not believe it. Yet, when analysing education of the Soviet period, it was difficult for ex-Soviet citizens (including historians) to distance themselves from individual memories and the need to explain "how it all was," forgetting that in order to understand self-experience, one needs a profound theoretical basis, as in all research. ${ }^{13}$

Public enthusiasm about access to new historical sources has promoted expansion of the community of historians, mostly among amateurs. In Estonia, the community-based Estonian Public Teachers Research Institute had been recognised by the local Ministry of Education in 1972 and gathered teachers interested in academic research. The institute had a section on the history of Estonian schools, which, during the 1990s, highlighted the role of past and current teachers in Estonian culture, ${ }^{14}$ activities of Estonian educators between 1918 and 1940, ${ }^{15}$ and other issues. The collection of the Estonian Public Teachers Research Institute contains much empirical data from various periods of Estonian education and provides material for comparative research.

Amateur historians in Latvia are widely represented in the annual collection of articles Era and Personality, first published in $2000^{16}$ when the history of education gained popularity amongst University of Latvia Master's and Doctoral programme students. The initiator of Era and Personality was a professional historian, prof. Aida Krūze. As Krūze has often stated, the primary motive for printing the first edition of Era and Personality was to publicise facts carefully collected and discovered by students. This collection of articles was published for 15 years and became a significant repository of biographies of famous and local teachers. ${ }^{17}$

The work of professional historians demands much scrutiny and is very time consuming, but during times of rapid social change, the public was not willing to wait for carefully developed studies. After the long years of silence, people wanted to tell their story or that of their families, or even the story of

${ }^{13}$ See K. Etherington, 'Reflexivity: Using Our 'Selves' in Narrative Research', in S. Trahar (ed.), Narrative Research on Learning: Comparative and International Perspectives, Symposium books, 2009 , p. 81.

${ }^{14}$ Eesti pedagoogika ja kool, XLII: Õpetajad kooli-, kultuuri- ja ühiskonnategelastena [Estonian pedagogy and school, XLII: Teachers as educational, cultural persons and public people], Tallinn, 1990; Eesti pedagoogika ja kool, XLVI: Õpetaja ja kooliajalugu [Estonian pedagogy and school, XLVI: Teachers and school history], Tallinn, 1992.

${ }^{15}$ Eesti pedagoogika ja kool, XLIX: Koolinõunikud koole nõustamas [Estonian pedagogy and school, XLIX: School counsellors in advising schools], Tallinn, 1998.

${ }^{16}$ A. Krūze (ed.), Laikmets un personība [Era and personality], Rīga, Raka, 2000.

${ }^{17}$ A. Nobik, I. Kestere, J. Gulzynska, 'History of Education Journals and the Development of Historical Research on Education in Eastern Europe (1990-2016), IJHE. Bildungsgeschichte. International Journal for the Historiography of Education, no. 2, 2019, pp. 141-155. 
the entire nation. Alan Wider has described this "necessity to tell" through studying the post-apartheid society in South Africa. ${ }^{18}$

There was a general lack of professionals in history, and, therefore, Baltic historians of education gladly accepted also those who were learning by doing. Historians of education are sometimes so delighted about the attention to their often-marginalised field that they create the illusion that the history of education is not a serious field of study: a researcher needs only enthusiasm, good will, and plenty of time for research in archives but does not require special skills in methodology. Local education history sometimes became a form of socializing less research, more partying. Unfortunately, this leads to degradation of the field to the hobby level and the belief that anyone with time and the desire can study history. In other words, competition is lacking in the small communities of historians of education, and amateurs are enthusiastically accepted.

In general, after regaining independence, the first studies of the history of education fulfilled their tasks with integrity: they discovered new sources and provided insight into the development of education, interpreting facts mainly in the context of European political history. Education history was freed from the simplified Soviet "class approach," and previously prohibited or distorted national stories were revealed to the public. Yet, these first studies lacked references to global historiography, prohibited behind the Iron Curtain for 50 years and still difficult to reach in the 1990s.

A new generation of researchers emerged during 1990s. They had been trained by Soviet-educated historians and education scholars; thus, the "new" national history was discovered together by learning from each other, but still without the application of modern global approaches and theories. Access to Western histories of education was limited due to insufficient funding (conferences and books published in the West were too expensive) and lack of foreign language skills.

Of 41 thesis developed in the Baltic States from 1990 to 2004, 37 (90.2\%) were devoted to the history of education in Estonia, Latvia, or Lithuania; $22(53.6 \%)$ authors included the history of education during the first period of independence in their research, and 10 (24.3\%) specifically researched the period from 1918 to 1940 . Five (12.1\%) doctoral theses focused on education under Soviet dictatorship, and 4 (9.7\%) were devoted to the history of education in the West. This expansion of geographic borders was important for the new narrative as during the Soviet era, Russia was posited as the centre of the history of education and cradle of all progressive educational ideas.

The history of various educational institutions was one of most popular topics for doctoral theses, ranging from kindergartens to universities and teacher training institutions. Preparation of theses in the form of overviews was quite understandable during this period: researchers were driven by the task to reveal the "new" history of education of the Baltic States in as short a period

\footnotetext{
18 A. Wieder, 'Testimony as Oral History: Lessons from South Africa,' Educational Research, vol. 33,
} no. 6, 2004, pp. 23-28. 
of time as possible and as extensively as possible, thus creating a framework for further studies that would be more focused on specific phenomenon in education. Descriptive theses were usually written in Latvia and Lithuania, but Estonia focused on specific problems of education right from the beginning.

The majority of doctoral theses were completed to receive a degree in education (pedagogy), not history. Thus, it was common to speculate that one could simply adopt past experience and apply it to the present, which threatened to degrade the history of education to a utilitarian or ideological level. ${ }^{19}$

\section{Entering the global community of historians of education}

Life in the "comfort zone" of national history could not last long as borders opened and the public of the Baltic states were able to compare the performance of domestic and foreign scholars. Also, the new generation of historians of education desired to improve their professional knowledge and skills as much as possible.

Following Soviet dictatorship, the conceptual development direction for education history was evident - of course, towards the West! Silova describes the situation in post-Socialism lands: ignoring or even denying Western ways was impolite and spoke to backwardness, and changes in the direction of the West were perceived as guarantors of progress, triumph, and a return to "normality." 20 The West in the history of education became a powerful argument. $^{21}$

But first, one needed to "find" the West, which was not easy in the 1990s when the Internet was still developing and personal computers were a luxury. Current information in a field as specific as the history of education could be found only in some scarce magazines in libraries and through discussion with the first foreign colleagues to visit the Baltics.

\footnotetext{
${ }^{19}$ Marc Depaepe in several works writes about utilitarianism in the history of education, e.g., M. Depaepe, 'Some Statements about the Nature of the History of Education', in K. Salimova, E. V. Johanningmeier (eds.), Why should We Teach History of Education, Moscow, The Library of International Academy of Self-Improvement, 1993, pp. 31-36; M. Depaepe 'Nenozimïbas ìpatnības. Pedagogijas vēsture skolotāju izglīîibä [Qualities of irrelevance. History of education in the training of teachers], in ATEE Spring University. Teacher of the 21 ${ }^{\text {st }}$ Century: Quality Education for Quality Teaching, Riga, University of Latvia, 2008, pp. 14-24; M. Depaepe, 'Why Even Today Educational Historiography is not an Unnecessary Luxury. Focusing on Four Themes from Forty-four Years of Research,' Espacio, Tiempo y Educación, vol. 7, no. 1, p. 240. ${ }^{20}$ I. Silova, 'Rediscovering Post-Socialism in Comparative Education,' in I. Silova (ed.), PostSocialism in not Dead: (Re)Reading the Global in Comparative Education, Emerald Group Publishing, 2010, p. 5; J. McNutt, 'What is Modernization? Eurocentrism and Periodization,' Encounters/Encouentros/Recontres on Education, no. 15, 2014, pp. 12-136.

${ }^{21}$ See B. Zymek, 'Das Ausland als Argument in der pädagogischen Reformdiskussion. Schulpolitische Selbstrechtfertigung, Auslandspropaganda und Ansätze zu einer Vergleichenden Erziehungswissenschaft in der internationalen Berichterstattung deutscher pädagogischer Zeitschriften, 1871-1952', Schriftenreihe zur Geschichte und Politischen Bildung, vol. 19, 1975.
} 
But while reaching the idealised West, historians of the "post-ness" space who desired to be part of "old" Europe encountered several problems. ${ }^{22}$ One of the most significant was that the regained national self-confidence of "new" Europeans and their enthusiastically presented "new" narratives of history were greeted with reserve and even suspicion in the West, for several political and professional reasons. As previously noted, master narratives of national history can be driven by utilitarian or ideological aims - strengthening of national identity and patriotism. ${ }^{23}$ Excessive feelings of belonging and solidarity with a specific group was perceived by the democratic public as a potentially manipulative of the individual and related to gaining political power. International, transnational, and global history was trending, but nationality was associated only with negative historical experience in Europe. Although it was Marx's idea to liquidate states, this had gained true popularity under capitalism: "non-state" and "non-territorial" concepts flourished in Europe. ${ }^{24}$ National perspective could also always be branded with narrow-mindedness in contrast to an international perspective or broad-mindedness.

In a nutshell, Europeans from the "post-ness" space soon understood that their joy in regaining national identity and positively traced national history narratives were welcomed and recognised only locally, at home. To fit into the common European scene, they needed to convert the national past into concepts of global history and explain it within the context of the global history of education. It required knowledge of foreign languages and time spent reading, a task that turned out to be much more difficult than gathering facts in archives.

While lack of funding and insufficient knowledge of foreign languages delayed Baltic historians' entry into the free world, researchers from the West were eager to study "new" European territories. They were greeted in the Baltics with the utmost respect and interest: they unveiled research achievements from the democratic world and served as guides on the path to the West. First, history of education books published in Western countries ${ }^{25}$ were delivered to Latvia by Goethe University Frankfurt professor Gunther Böhme. In 2002 for the first time, Baltic historians of education attended the main event for

${ }^{22}$ See I. Kestere, 'History of Education and the Struggle for Intellectual Liberation in PostSoviet Baltic Space after the Fall of the Berlin Wall, Paedagogica Historica, vol. 50, no. 6, 2014, pp. 744-851; I. Kestere, 'The "Nation" in the History of Education from an European "Postness" Perspective,' Bildungsgeschichte. International Journal for the Historiography of Education, vol. 6, no. 1, 2016, pp. 109-111.

${ }^{23}$ F. van Alphen, M. Carretero, 'The Construction of the Relation Between National Past and Present in the Appropriation of Historical Master Narratives,' Integrative Psychological and Behavioural Science, vol. 49, no. 3, 2015, pp. 512-530.

${ }^{24}$ G. Schöpflin, Politics, Illusions, Fallacies, Tallinn, TLU Press, 2012, p. 155.

${ }^{25}$ G. Böhme, H-E. Tenorth, Einführung in die Historische Pädagogik, Wissenschaftliche Buchgesellschaft, 1990. 
the international community of the historians of education - the International Standing Conference for the History of Education (ISCHE). ${ }^{26}$

International cooperation was important for several reasons: 1) It allowed comparison of knowledge and scientific skills with people who had longpossessed the necessary resources, ones that were not available in the USSR: systemic and versatile education, language skills, travelling and publishing opportunities, and approbation of research in an intellectually open professional network; ${ }^{27}$ 2) Historians could study global historical narratives and explain local history from this perspective, learning to describe their history to an international audience that usually had little, if any knowledge about the Baltic states, not to mention nuances of educational history; and 3) They could acquire new ideas and methodology for research of local history.

But going West also caused conflict among local communities of education historians, dividing national history enthusiasts into camps supporting traditional forms or implementation of the latest Western trends. The former continued to gather and describe facts from national archives, interpreting them mainly within the context of political history. The latter got carried away with application of various social science theories in historical studies, sometimes allowing the theoretical framework to overshadow logical reconstruction of the history narrative.

\section{Baltic States from the perspective of the global history of education}

During the 1990s, an inevitable question was raised - what exactly does the development of the history of education in a Western direction mean? To reveal modern patterns in the global field of education history, we analysed several academic articles written by outstanding and internationally recognised scholars from various regions. ${ }^{28}$ They were also selected because of their special focus on the problems of education history as an academic research discipline.

\footnotetext{
${ }^{26}$ See more about activities of the historians of education of the Baltic States in I. Kestere, 'The Baltic Historians of Pedagogy and the International Standing Conference for the History of Education,' Acta Baltica Historiae et Philosophiae Scientiarium, vol. 2, no. 2, 2014, pp. 127-132.

${ }^{27} \mathrm{M}$. Depaepe mentions advantages of Westerners in research connecting them with Darwinism evolutionary theory ("the fittest survives"): See M. Depaepe, 'It's a Long Way to... an International Social History of Education: in Search of Brian Simon's Legacy in Today's Educational Historiography', History of Education, vol. 33, no. 5, 2004, p. 540.

${ }^{28}$ D. Tröhler, 'Tracking the Educationalization of the World: Prospects for an Emancipated History of Education,' Pedagogika, vol. 67, no. 3, 2017, pp. 211-226; G. McCulloch, 'New Directions in the History of Education,' Journal of International and Comparative Education, vol. 5, no. 1, 2016, pp. 47-56; R. Hofstetter, A. Fontaine, S. Huitric, E. Picard, 'Mapping the Discipline History of Education,' Paedagogica Historica, vol. 50, no. 4, 2014, pp. 871-880; R. Sani, 'History of Education in Modern and Contemporary Europe: New Sources and Lines of Research', History of Education Quarterly, vol. 53, no. 2, 2013, pp. 184-195; B. Finkelstein, 'Teaching Outside the Lines: Education. History for a World in Motion, History of Education Quarterly, vol. 53, no. 2, 2013, pp. 126-138; R. Aldrich, Lessons from History of Education. The selected works of Richard Aldrich, London and New York, Routledge, 2006.
} 
Experts agreed on several points regarding objectives of modern history of education: they called for emancipation of national restraint and discovery of internationally significant topics such as "lost voices" of individuals, "travelling ideas", reality of schooling, education of specific social groups (middle class, gender, ethnicity, and disability), and education outside traditional educational institutions (private organisations, associations, and representatives of civil society).

On this basis, we developed a table of topics of doctoral theses defended in the Baltic countries (see Table 1), which reveals the "fresh" or "modern" topics related to the history of education and those that provide a general overview of educational development in the Baltic states. Statistically, our results are as follow:

1) History of ideas. Travelling ideas - $24.4 \%$;

2) Realities of schooling - 24.4\%;

3) Lost voices. Specific social groups - 19.5\%;

4) Education outside traditional educational institutions - 7.4\%; and

5) General topics. Overview of the development of education in the Baltic States - 24.3\%.

As we can see, the majority of research was devoted towards the history of ideas, realities of schooling, and historical overviews of Baltic education. As previously mentioned, ridding history of Soviet ideology was important, which brought new trends in research of local education history such as analysis of the formation of the child's world view at school, opinions about pedagogical relations, and pedagogical ideas expressed by people who were not teachers. Expansion of the teaching profession included not only teachers working in traditional educational establishments but also writers, philosophers, composers, and public figures contributed to the widening of the educational field outside the walls of the school called for by global historians of education such as Lawrence Cremin ${ }^{29}$ and Roberto Sani. ${ }^{30}$

Theses on the realities of schools can be divided into two groups: 1) subject specific teaching/learning methods (e.g., mother tongue, mathematics, physical education, music) and 2) the upbringing process at school (e.g., work, aesthetic, national). Didactics and upbringing were key areas in Soviet educational sciences that were thoroughly studied during the Soviet era, developing detailed research methodology. Only research on the history of national upbringing can be considered new in this area, paradoxically acceptable to neither Soviet pedagogy, which perceived everything national with suspicion as a reminder of Baltic national independence, nor to the West where 'national' was identified with radical right-wing political views and Europe's sad historical experience in the 1930s-40s. But national upbringing in the Baltic community was understood as citizenship education within newly independent and democratic states.

${ }^{29}$ L. A. Cremin, Traditions of American Education, New York, Basic Books, 1977, pp. 127-128.

${ }^{30}$ R. Sani, 'History of Education in Modern and Contemporary Europe: New Sources and Lines of Research', History of Education Quaterly, vol. 53, no. 2, 2013, p. 184. 
Comparatively, a significant number of theses were devoted to the history of education of specific social groups, a completely new topic in the Baltics. Soviets proclaimed a perfect, homogenous society in which gender and national differences were levelled out to the maximum but where people with special needs did not really fit. Therefore, only a few social groups participated in creating Soviet history with a clear message: oppressed (peasants, workers) versus oppressors (capitalists), sometimes joined by victimised women who were denied education by capitalists or other oppressors but rescued by Soviet power. Studies about education of minorities (e.g., Russian and Jewish), the exile community, and people with special needs were also modern from the global perspective: Richard Aldrich invited historians in 2006 "to rescue from oblivion those whose voices have not yet been heard and whose stories have not yet been told." ${ }^{11}$ Also, today we hear invitations to search for "top-down" narratives and "potentially lost voices." 32

In general, we can say that education researchers from the Baltic states entered the world in the 1990s with an extensive array of topics that may have not stood out with originality, but they revealed "virgin" territory - new sources and discussion of education of various social groups under totalitarian/ authoritarian rule.

\section{Conclusion}

During the 1990s and the early $21^{\text {st }}$ century, Baltic historians of education honestly tried to solve the professional tasks brought forth by the societies of the new nation states and increase their prestige inside the academic community. Local histories of education were rewritten, eliminating the simplified Soviet "class war" standards and interpreting newly available archives. Yet, we should admit that the new national story was coloured in ideology and directed towards local public demand - expose the communist dictatorship, legitimise national statehood, acknowledge the significance of education in the development of the nation, and prove the long-standing ties of the Baltic states with Western Europe, not just Russia, as proclaimed during the Soviet era. Creation and strengthening of nationalism, patriotism, and optimism with the help of past images is typical of periods of transition, transformation, and confusion. ${ }^{33}$ Development of education in the Baltic states was mostly explained in the context of European political history and not the history of education. For

${ }^{31}$ R. Aldrich, Lessons from History of Education. The selected works of Richard Aldrich, London and New York, Routledge, 2006, p. 18.

32 G. McCulloch, 'New Directions in the History of Education,' Journal of International and Comparative Education, vol. 5, no. 1, 2016, p. 51; B. Finkelstein, 'Teaching Outside the Lines: Education History for a World in Motion, History of Education Quarterly, vol. 53, no. 2, 2013, p. 128.

${ }^{33}$ M. Tamm, 'Displaced History? A New "Regime of Historicity" among the Baltic Historians in Exile (1940s-1960s),' Storia della Storiografia/Histoire de l'Historiographie/History of Historiography/ Geschichte der Geschichtsschreibung. Rivista internazionale. Revue internationale International Review. Internationale Zeitschrift, vol. 69, no. 1, 2016, p. 136. 
the most part, the "new" history of education was written for the local, national "market."

At the same time, public pressure required them to catch up Europe, ${ }^{34}$ but this required the capacity to accumulate the knowledge offered. ${ }^{35}$ Communication with the global community of historians formed slowly as information about the community's activities, funding, and knowledge of foreign languages was also insufficient. Time was needed to learn how to tell the narrative of Baltic history of education to an international audience without an overload of locally significant facts that were not understandable or interesting to the global community. One had to look for large narratives, problems, and phenomenon in which to attribute the newly discovered local facts. Most successful work in this direction was about education of various social groups ("lost voices"), such as ethnic minorities and education of the Baltic exile community.

When contemplating the future of the history of education of the Baltic countries, one can refer to Barbara Finkenstein who states that attention should be focused not only to the common but also the different by asking - how to understand that? ${ }^{36}$ Historians of education of the Baltic countries believe that the local is not understandable just through a global perspective, but global history can also be understandable through a national perspective. ${ }^{37}$

${ }^{34}$ I. Silova, 'Rediscovering Post-Socialism in Comparative Education' in I. Silova (ed.), PostSocialism in not Dead: (Re)Reading the Global in Comparative Education, Emerald Group Publishing, 2010, p. 13.

${ }^{35} \mathrm{~J}$. McNutt, 'What is Modernization? Eurocentrism and Periodization,' Encounters/Encouentros/ Recontres on Education, no. 15, 2014, p. 134.

${ }^{36}$ B. Finkelstein, 'Teaching Outside the Lines: Education History for a World in Motion, History of Education Quarterly, vol. 53, no. 2, 2013, p. 127.

37 See also M. Tamm, 'Writing Histories, Making Nations: A Review Essay', Storicamente, no. 12, 2016; I. Kestere, "The "Nation" in the History of Education from an European "Postness" Perspective, Bildungsgeschichte. International Journal for the Historiography of Education, vol. 6, no. 1, 2016, pp. 109-111. 
Table 1. Doctoral Theses in History of Education defended in the Baltic States from 1990 to 2004

\begin{tabular}{|c|c|c|}
\hline Estonia & Latvia & Lithuania \\
\hline \multicolumn{3}{|c|}{ Lost voices. Specific Social Groups (Total 8) } \\
\hline \begin{tabular}{|l|} 
1) Aldo Kals. The Role of \\
Education in the History \\
of Integration of the \\
Visually Impaired in \\
Estonia. University of \\
Tartu, 1999 \\
2) Lauri Lindström. Album \\
Academicum Universitatis \\
Tartuensis 1918-1944: \\
Tallinn Pedagogical \\
University, 2001 \\
3) Aivar Jürgenson. Identity \\
and Territoriality of \\
Siberian Estonians. \\
Tallinn Pedagogical \\
University, 2002 \\
4) Vello Paatsi. Formation \\
of the Natural Science \\
Outlook of Estonian \\
Peasants Rural Schools \\
(1803-1918). Tallinn \\
Pedagogical University, \\
2003 \\
5) Inna Järva. Educational \\
Changes in Three \\
Generations of Russian \\
Families Living in Estonia: \\
a socio-cultural approach. \\
Tallinn Pedagogical \\
University, 2004
\end{tabular} & & $\begin{array}{l}\text { 1) Valentinas Vytautas Toločka. } \\
\text { Development of Education for } \\
\text { the Blind in Lithuania until } \\
\text { 1940. Vilnius University, } 1992 . \\
\text { 2) Sada Petružienè.Education of } \\
\text { Jewish Children in Lithuania: } \\
\text { Development of Gymnasiums } \\
\text { and Modern Secondary School. } \\
\text { Klaipeda University, Vytautas } \\
\text { Magnus University, 2000. } \\
\text { 3) Benediktas Šetkus. The School of } \\
\text { National Minorities in Lithuania } \\
\text { during the Period of 1918-1940. } \\
\text { Vilnius Pedagogical University, } \\
\text { 2000. }\end{array}$ \\
\hline
\end{tabular}

Ideas. Travelling Ideas and Practices (Total 10)

1) Tiina Kala. Late Medieval 1) Jel̦ena Davidova. Literary Culture and School Manuscripts: handbook of Dominican Friar David Sliper from Tallinn Friary. University of Tartu, 2001 Pedagogic Ideas of J. S. Bach. University of Latvia, 1997

2) Baiba Kallke. Teachers-Writers in the Development of Pedagogical Theory and Practice in Latvia from 1900-1940. University of Latvia, 2002
1) Ona Tijūnienè. The Problem of Pedagogical Relations in Pedagogical Thought in Lithuania in the First Half of the $20^{\text {th }}$ Century. Vilnius University, 1990.

2) Jolanta Vaičiūnaitè. The American School as a Social Educational Phenomenon.

Kaunas University of Technology, Vytautas Magnus University, Lithuanian Sports, 1997.

3) Diana Šileikaite. The System of Pedagogy of Immanuel Kant. Vilnius University, Kaunas University of Technology, 2002.

4) Džiuljeta Maskuliūnienè. Lithuanian Didactic Prose of the $19^{\text {th }}$ Century. Vilnius University, 1999. 
Continue Table 1

\begin{tabular}{|c|c|c|}
\hline Estonia & Latvia & Lithuania \\
\hline & & $\begin{array}{l}\text { 5) Lilia Rašimienè. Komensky's } \\
\text { Idea of "The Mother's School" in } \\
\text { Lithuania - late } 19^{\text {th }} \text { century - } \\
\text { first half of the } 20^{\text {th }} \text { century). } \\
\text { Klaipeda University, Vytautas } \\
\text { Magnus University, 2000. } \\
\text { 6) Aušrine Zulumskyte. } \\
\text { Development of the Child's } \\
\text { World View in Lithuanian } \\
\text { Primary SchoolS: the aspect of } \\
\text { the curriculum in 1918-198., } \\
\text { Klaipeda University, 2000. } \\
\text { 7) Kristina Mačiulyte. Ideas of } \\
\text { Education in Fugative Sermons } \\
\text { in the Grand Duchy of Lithuania } \\
\text { in the Second Half of the } 18^{\text {th }} \\
\text { Century. Institute of Lithuanian } \\
\text { Literature and Folklore, 2004. }\end{array}$ \\
\hline \multicolumn{3}{|c|}{ Reality of Schooling (Total 10) } \\
\hline $\begin{array}{l}\text { 1) Karl Kaalep. Justification } \\
\text { of Content and } \\
\text { Methodology of Special } \\
\text { Schools' Mother Tongue } \\
\text { Teaching. University of } \\
\text { Tartu, 1993 } \\
\text { 2) Martin Hallik. Role of } \\
\text { Professors and Students } \\
\text { of the University of Tartu } \\
\text { in 'Studia Humaniora } \\
\text { Orientalia' (1802-1940). } \\
\text { University of Tartu, 2001 } \\
\text { 3) Roman Kallas. Tradition } \\
\text { of Teaching Estonian } \\
\text { Literature in the } \\
\text { 20 th Century Russian- } \\
\text { Language Schools. Tallinn } \\
\text { Pedagogical University, } \\
\text { 2003 }\end{array}$ & 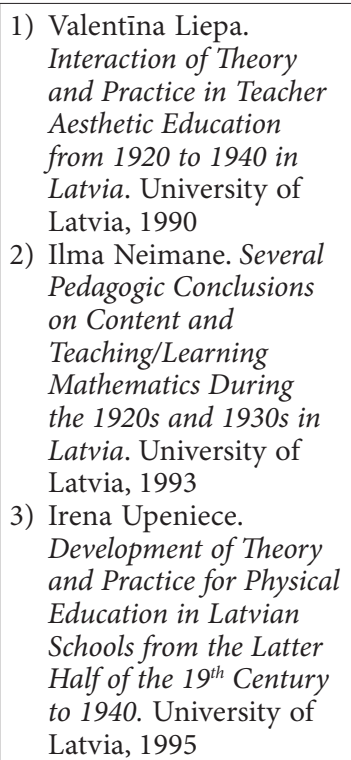 & $\begin{array}{l}\text { 1) Danute Petrauskaitė.Klaipeda } \\
\text { Music School as a Pedagogical } \\
\text { System and its Importance to } \\
\text { Music Education in Interwar } \\
\text { Lithuania. Vilnius University, } \\
1993 \\
\text { 2) Asta Širiakoviene, Vocational } \\
\text { Training in General Education } \\
\text { Schools in Lithuania } \\
\text { (1940-1990). Vilnius University, } \\
\text { 1993 } \\
\text { 3) Remigijus Motuzas, Pedagogical } \\
\text { Trends in the Development of } \\
\text { Secondary General Education } \\
\text { Schools in Lithuania in } \\
\text { 1918-1940. Vilnius University, } \\
\text { 1994 } \\
\text { 4) Vidimantas Raudys. National } \\
\text { Upbringing in Lithuania's } \\
\text { Elementary Schools in } \\
\text { 1918-1940. Klaipeda University, } \\
\text { 1998 }\end{array}$ \\
\hline \multicolumn{3}{|c|}{ Education outside Traditional Educational Institutions (Total 3) } \\
\hline $\begin{array}{l}\text { 1) Anne Valmas. Publishing } \\
\text { Activities of Estonians } \\
\text { outside Estonia from } \\
\text { 1944-2000. Tallinn } \\
\text { Pedagogical University, } \\
2003\end{array}$ & & $\begin{array}{l}\text { 1) Tamara Vainauskienè. } \\
\text { Formation and Development } \\
\text { of Vocal Pedagogy in Lithuania } \\
\text { (1919-1949). Lithuanian } \\
\text { Academy of Music and } \\
\text { Theatre, } 1993 \\
\text { 2) Vida Pukiene. The Lithuanian } \\
\text { Education Societies in the Early } \\
\text { 20 Century (1906-1915). } \\
\text { Vilnius University, 1993 }\end{array}$ \\
\hline
\end{tabular}




\section{Continue Table 1}

\begin{tabular}{|c|c|c|}
\hline Estonia & Latvia & Lithuania \\
\hline \multicolumn{3}{|c|}{ General Topics. Overview of Development of Education in the Baltic States (Total 10) } \\
\hline & $\begin{array}{l}\text { 1) Aivars Rubenis. History } \\
\text { of the Development of } \\
\text { Compulsory Schools } \\
\text { in Latvia and Their } \\
\text { Pedagogic Values } \\
\text { from } 1919 \text { to1940. } \\
\text { University of Latvia, } \\
1990 \\
\text { 2) Leonards Žukovs. } \\
\text { Development of } \\
\text { Education of "Folk } \\
\text { School" Teachers in } \\
\text { Latvia until 1940. } \\
\text { University of Latvia, } \\
\text { 1993 } \\
\text { 3) Irēna Saleniece. } \\
\text { Political Management } \\
\text { of Schools in Latvia } \\
\text { (1918-1934). University } \\
\text { of Daugavpils, 2002 }\end{array}$ & $\begin{array}{l}\text { 1) Bronè Čèsnaitè.Organisation of } \\
\text { Obligatory Secondary Education } \\
\text { in Lithuania in 1975-1987. } \\
\text { Vilnius University, 1992 } \\
\text { 2) Romaldas Navickas. Universal } \\
\text { Secondary Education in } \\
\text { Lithuania in 1966-1988: } \\
\text { Aspect of Management. Vilnius } \\
\text { University, } 1992 \\
\text { 3) Vitalija Gražienè. Pedagogical } \\
\text { Features of Kindergarten in } \\
\text { Lithuania before 1940-roots, } \\
\text { development and establishment } \\
\text { of systems. Vilnius University, } \\
\text { 1993 } \\
\text { 4) Darius Staliūnas. Government, } \\
\text { Society and Higher Education } \\
\text { in Lithuania in the Middle of } \\
\text { 19th - Beginning of 20 th Century. } \\
\text { Vytautas Magnus University, } \\
\text { 1997 } \\
\text { 5) Artūras Grickevičius. Vilnius } \\
\text { Papal Seminary in 1583-1655, } \\
\text { Vytautas Magnus University, } \\
\text { Institute of Lithuanian History, } \\
\text { 1997 } \\
\text { 6) Aušra Žemgulienè. } \\
\text { Development of training of } \\
\text { primary school teacher in } \\
\text { Lithuania in 1918-1940. Vilnius } \\
\text { Pedagogical University, 2000 } \\
\text { Sigita Montvilaitè. Maturity of } \\
\text { Education Science in Lithuania } \\
\text { in the First Half of the Twentieth } \\
\text { Century. Vilnius Pedagogical } \\
\text { University, 2002 }\end{array}$ \\
\hline Total 10 & Total 8 & Total 23 \\
\hline \multicolumn{3}{|c|}{ Total 41} \\
\hline
\end{tabular}

